\title{
SOME REMARKS REGARDING THE IMPORTANCE OF HUSSERL'S PHENOMENOLOGY TODAY
}

\begin{abstract}
Husserl's Phenomenology re-opens our ability to ask what something like 'Ethics' could mean and be, i.e. not to judge something or someone ex cathedra 'in' the horizon of ethics but to inquire about this horizon itself.
\end{abstract}

Keywords: ethics, phenomenology, philosophy, metaphysics, tradition, Europe.

With the little space given here we do not wish to write about the issues of ethics as a special area of Husserl's phenomenological analyses (at least two large volumes of his texts concerning ethical and axiological issues are already published). We wish to limit our field of investigation only to highlight some of the key questions and make some connections which have to be shown only in a limited form. We also cannot elaborate this in detail and so we limit ourselves mainly to putting some questions. The main question will be as follows: Why is Husserl's phenomenology so important for our "here and now"?

This "here and now" we do not consider as some up-to-date actuality, which assumes a horizon of physical or inner-worldly time and thus a certain way of self-understanding, a certain metaphysics of the actus and actuality, but a correlate of time-consciousness, "in" which the meaning of our "who we are" together with the way, "how we are" is constituted historically on a transcendental level (I am not able to preserve in English the difference between two German terms: Historie and Geschichte or - even better - die Gewesenheit). Europe's crisis does not consist primarily of its economic, political and social issues - these are themselves the consequences of our inability to answer the questions inherited in our tradition, or the questions which established our tradition as such and "from" which our Europe as Europe is living. What we want to question is not whether something is "in" or "outside" of Europe, but the Europe itself; what has to be questioned is not something "in" ethics but it is the ethics itself and that is precisely what Husserl's phenomenology is able to do. 
Our identity as Europeans does not lie in the magical incantation of "competitiveness" which is supposed to legitimize, i.e. establish that "where-from", the standpoint from which we comprehend the bureaucratic decisions and which in the last instance subordinates all human life to the "market" (by this title we address the irresponsible, i.e. the non-answered call to regulate our human relationships as human, which, in this irresponsibility has the form of war of a higher order, and the violence of this war is something obvious and as such invisible - here we are far backwards and underdeveloped compared to Husserl's idea of "social mathesis" ("Mathesis der Sozialität", Husserl 2004, p. 58-60), we are not able yet to put this question properly) as the last regulating instance, and that is how the power apparatus of a higher order, designed for an emancipated citizen whose political liberty is the other side of the same coin of economical liberty to sell his own labor force in the market-place.

Nevertheless, also Chinese or Martians can be competitive, while Europe is in its sense established through opening the question regarding the absolute foundation of our life in relation to the truth. European as European is the one who has opened this ability to regulate his life through the insight (in German: Einsicht, Einblick), to whom the ability and possibility to ask about the validity of the knowing what he knows is opened: from where do I know, that what I know, I know (is it actually knowing and not a mere assumption, doxa in Plato's sense)? (science as the knowing meaningful as the answering of this question), and to whom in all his life the ability to ask about the good itself is opened: what is good as such and what is good for me? (freedom as freedom to my "self", opened through the Delphic "gnothi seauton", "know your self"), or how Husserl puts it in the form of objective imperative: "Do the best from the achievable good within your own practical sphere!” (in German: “Tue das Beste unter dem erreichbaren Guten innerhalb deiner jeweiligen praktischen Gesamtsphäre!”, Husserl 1988, p. 142). This means that Europeans as such have in their traditional transmission of sense of the "world" and their "self" an open ability not to be enclosed into the world and living and lived situations, which they are set "in" and merely react to them, they are able to transcend every living-situation through the question "what is truly good here and now?"

The intention to seek the truth as such does not mean that every European becomes actually a scientist or philosopher and that everyone's life in Europe is dedicated to seeking their "self", but this possibility is opened for them. What is important here consists of the foundation of the new horizon of the "world" as universum - I elaborated this feature of "universum" with respect to the European tradition and science elsewhere (Rybák 2012; 2013), but there is still much to be done. To Europe belongs also the unity in manifold - one could say the uni-versity - as an intrinsic character of Europe regarding which a dialogue, the way to seek the truth through ("dia-") the opposite meanings, is only the other side of the same 
coin, as in this mathematical example: if something is a right-angled triangle, it does not mean that it is not a triangle.

However, one also could argue that in Europe there are whole nations or groups which totally do not correspond with the European idea and which even betrayed it. Here one cannot argue with mathematical examples (because - to put it simply - a wrong triangle is not a triangle at all), but let me use the example from the animal kingdom: a vicious dog or a three-legged dog is still considered to be a dog. In the spiritual sphere, the one who betrayed in any way his own essence can do it precisely because he has this essence - in a spiritual sphere. I am able to betray my "self", at least this possibility always exists and this self-responsibility, responsibility for my "self" is an essential possibility here.

The "crisis" from the Greek krinein does not mean some disapproving or giving counterargument, putting two different meanings against each other (as the media continually "pour into our heads" in the genre of "debates" or "talks"), but the very question about the conditions of possibility, the pre-conditions, "through" which we enter into "our" situation (and "in" this entering the meaning of "our" is constituted). Only here the knowing in the sense of permanent knowing, episteme, which does not concern the validity limited to the corresponding situation with which it disappears, but which has omnitemporal sense, is opened.

In this sense we could say that our "here and now" is characterized by the fact that even the crisis itself is in crisis, because, as Europeans, we do not face the tasks "in" the horizon of Europeanism, but the theme which appears more and more before us, is this horizon itself, which "ceases to function", i.e. the phenomena concerning their types, which we encounter within this horizon are more and more incomprehensible and their type is more and more confusing (philosophers and sociologists are speaking about "liquidity"), so that we encounter more and more problems, which escape our comprehension and which we cannot even identify and thus see it as "some-thing", and all this is not a phenomenon on some scientific or theoretical level, but within our everyday life and its practices.

Therefore, even our ability to keep our eyes able to see is in crisis; to "see" how our University and school as such are liquidized as the ground, on which and within which our Europeanism, our "who we are" is living through our tradition. This liquidation occurs not primarily through political or economic pressure to transform the University into expert schools, but this pressure and transformation is an effect of the way we think and see. Already ancient people knew that to bereft some community of their identity in this sense who "we" are (their "gods" were precisely what identified their "us" through identification of what we regard as important) means to master this community. In crisis is also our ability to differentiate the knowing itself in the sense of episteme and the knowing through which we operate with something, the knowing how something could be manageable ( $k n o w$ -how), as the knowing of experts or Fachidiots. We have already lost the ability to comprehend the meaning of the first one, not only in science transformed into 
mere technological operations subjected to market and marketing logic, but also in our society as such. Sciences in their misunderstanding only in a passive way handed down people, who are able to comprehend only facts: "Merely fact-minded sciences make merely fact-minded people." (Husserl 1970, p. 6), who are blind to Ideas: „Blindness to ideas is a kind of psychical blindness; because of prejudice one becomes incapable of bringing what one has in one's field of intuition into one's field of judgment." (Husserl 1982, p. 41) These Ideas (Ideen) in Cartesian metaphysics, as a ground of obvious and as such non-visible assumptions of modern science are interpreted as the mere ideas (Vorstellungen; it is difficult to differentiate Vorstellung and Idee using English language).

Husserl's phenomenology is important within our European history (Geschichte) because (and insofar as) it opens up the ability to see it as such and to apprehend it through the radical question about the sense "in" and "from" which we live, using the reductive methods of re-activating these questions together with their horizon "in" which they arise, making this horizon visible. If we are not able to consider this horizon, we only passively take over the way of answering. What we want to say here is that the answers are what is left of our tradition, but we forgot the original questions, which these answers answered. Or, to put it in another way: when do I think? - only insofar as I am able to comprehend the issues, which I cannot answer in advance and which I am not able to answer within the knowledge "in" which I am orienting my self. These issues were called by the Greeks "aporias" (late form of this way of thinking may be found in the $3^{\text {rd }}$ book of Metaphysics from Aristotle). In this sense, phenomenological intention "to the things themselves!" means to think, not to let thinking be the mere "logical economy" (logische Wirtschaft, Husserl 1974a, p. 375), a management of the answers inherited in our tradition.

By all this we do not want to say that the crisis lies only in the intellectual or theoretical sphere or that it could be solved within it. The objection of intellectualism raised against Platonic philosophy is a retrospective illusion as a result of changed horizon in which the words "thinking" and "knowing" are interpreted - late consequence of this is psychologization of these. Is it not some kind of dissection of the living human in action in this psychological analyzing? How much the sense of Ethics is misunderstood, how much human being must be emptied out (nihilism), so that it would be possible to objectify, to psychologize and "measure" Ethics?

However, this relationship to our "self" and to the "world" is not something what is happening in the world in a form of some psychological process. This relationship concerns the way how we are on the whole, which also is not in the world. The moralizing point of view is false: there is no such view ex cathedra, which one could take. Here, Comenius' idea of Panorthosia is important. Husserl is a philosopher who showed that the assumption of the "world", in its obviousness non-visible, is constitutive not only in the realm of the natural attitude in the context of our lived-experience, but that it also is a constitutive layer in all metaphysical a scientific tradition, "in" and "through" which the sense of philosophy and of Europe as such 
is living. In this sense the phenomenological epoché makes possible to encounter not only the issues in the broadest sense "in" the world, but also this encountering itself, or, to put it in other words, to ask the question "who" and "how we are" (Seinsweise). Because the human being, as a being who has the logos, is not only "in" the world, but has a relationship to his "self" and that relationship itself does not occur in the world. Encountering of issues in the world as such is not understandable as occurring in the world, knowing is not some psychological process which modern science describes, as Husserl shows in his critique of psychologism. The analysis of our human way of being in psychologically defined abilities, will, intellect, fantasy, memory, emotion and affectivity is indeed the obvious heritage of the metaphysical tradition, it conceives the human being as an entity in the world, or, in other words, the being of this entity is in advance interpreted as an identity of the natural being which, comparing to the other beings, has an intellect in addition. After his Ideen had been published, Husserl became aware of this heritage (which was his target at least from his Logical Investigations); he became aware, that by the adoption of Brentano's division of the acts into ideas, judging and willing this psychological heritage is back.

The primacy of theoretical, or objectivating acts with their doxic quality is itself a legacy of the metaphysical pre-sumption of the world against which phenomenology is pre-theoretical in the sense that it wants to clarify (aufklären) also the very foundation of the theoretical region. While making this clear, phenomenology does not want "to interfere" with the theoretical attitude, that would mean to make assumptions, as if the correlates of the scientific attitude were the primary sense of being. Instead of analysing the objective relations and their correlative attitudes, the "return" to the transcendental subjectivity, or, as Husserl says, phenomenology must be an egology. That is where the issue of self-responsibility (Selbstverantwortung) comes to light. The "self" here does not mean the ego, but the transcendental "wherefrom" something could be encountered. Human being does not possess his "self" in advance, but he is (Seinsweise), or rather his is occurs in such way that at any moment he re-sponds (lat. spondere means "to pledge", to be able to stand for something) to the question "who you are in your own "self"? Ethics or "goodness" then is not something which one can realize, respectively what could be understandable within a metaphysical horizon of realization - it does not concern facts, it is not a matter of fact and in this sense there is no applied ethics if one conceives an application as a realization of something what is an ideal. What it does concern is our own relationship to the "world" and to our "self".

In a metaphysical division between real and ideal, factual and essential the universalisation machine is constructed "within" the horizon of realization. Against this view, Husserl shows that formal laws regulating a priori everything contextand situational-centered (which has its own material a priori) are not something universal, which, to put it in a Hegelian way, mediates itself through the individual with itself, so that the whole is not something real while it makes possible to let 
something be encountered as some-thing. Therein lies Husserl's distinction between formal and material: the whole as a formal category is not something on the entity (either on the substrate side or the predicative one), but is the formal moment, which has no material correlate, but without which nothing could be encountered - on the noetic side it is the intention of the unity, which goes-through (hindurchgeht) anything given in a way that this anything is constituted "in", "through" this unity.

In other words, primarily we do not know what something like Ethics could be, we even do not know that we do not know it. Why? It is because we know it always already "in" the always already constituted horizon of Ethics. This horizon we have to put in question or there would be no Ethics at all. To understand the constitutional problem and the claim of Ethics means: be able to make clear considering of my "self", why and in what sense it is good to be honest. However, this clarification is not an issue of universal laws and rules, but is understandable only considering the erotic way of being human. The problem is not in the question of what is good in the horizon of ethics, but this horizon itself. Husserl's Selbstverantwortung is the title for this erotic re-sponding, for the liability for our "self" as such - it is Besinnen, "in" which "a wonderful phenomenon of self-determination" ("wunderbare Phänomen der Selbstbestimmung”, Husserl 2004, p. 162) occurs.

Only the being whose "mode of being" is constituted through the ability to relate itself to his "self", is able to understand something as good or bad. This relation to his "self" is named erós in Plato and this word does not name some psychological property or process, but this very way of being human as human. Also "good" is not some property or predicate of entities and as soon as it is interpreted this way, it becomes an issue of managing and creating of entities, speaking about values as something which has to be realized (in the horizon "to be" = "to be real"). Referring to ethics as such, through which we want to justify something which is a matter of fact, where we ex cathedra judge about what "should be", there we are trafficking with "good", we demean it to a mere object, reason, instrument for a realization of something, to say it with Gorgias, "we make the weaker reason into stronger", because when we understand the good as the reason for something factual (if something like that would not be something absurd), it will be the weakest, the slightest reason or cause.

\section{References}

Husserl E. (1970). The Crisis of European Sciences and Transcendental Phenomenology. Evanston: Northwestern University Press.

Husserl E. (1976a). Die Krisis der Europäischen Wissenschaften und die Transzendentale Phänomenologie: Eine Einleitung in die phänomenologische Philosophie. Haag: Nijhoff.

Husserl E. (1976b). Ideen zu einer reinen Phänomenologie und phänomenologischen Philosophie. Haag: Nijhoff. 
Husserl E. (1982). Ideas Pertaining to a Pure Phenomenology and to a Phenomenological Philosophy, First Book. General Introduction to a Pure Phenomenology. Haag: Martinus Nijhoff.

Husserl E. (1988). Vorlesungen über Ethik und Wertlehre 1908-1914. Dordrecht: Kluwer Academic.

Husserl E. (2004). Einleitung in die Ethik: Vorlesungen Sommersemester 1920 und 1924. Dordrecht: Kluwer.

Rybák D. (2012). Husserluv vztah k náboženství a problém geneze náboženského postoje vưbec v souvislosti analýz „žitého světa“ (Lebenswelt). In: J. Vogel, Z. Kučera, D. Vik (eds). Náboženství a teologie ve filosofické reflexi: mezi modernou a postmodernou. Chomutov: L. Marek, pp. 85-113.

Rybák D. (2013). Fenomenologie křestanského lidství v souvislosti analýz žitého světa. In: J. Vogel, D. Vik (eds). Kapitoly z dialogu mezi vědou a vírou. Chomutov: L. Marek, pp. 67-80.

\section{UWAGI DOTYCZACE ROLI FENOMENOLOGII HUSSERLA W DZISIEJSZYCH CZASACH}

Streszczenie: Fenomenologia Huserrla otwiera na nowo możliwość zapytania o to, co etyka może współcześnie oznaczać i czym być. Autor artykułu uważa, że z całą pewnością nie powinna być ona osądzaniem rzeczy ani osób w przyjętym horyzoncie etycznym, lecz przede wszystkim pytaniem o ten horyzont sam w sobie.

Słowa kluczowe: etyka, fenomenologia, filozofia, metafizyka, tradycja, Europa.

David Rybák - PhD., assistant professor in the Social Sciences and Philosophy Department, Faculty of Education, Charles University in Prague. Main publication: Filosofie Jaroslavy Peškové (2010), The Educational Aspect of Phenomenological Reduction (2014). E-mailaddress: david.rybak@pedf.cuni.cz. 